Nova Southeastern University

Florida

NOVA SOUTHEASTERN

UNIVERSITY

NSUWorks

Marine \& Environmental Sciences Faculty Articles Department of Marine and Environmental Sciences

$1-15-2011$

\title{
Suppression Subtractive Hybridization PCR Isolation of cDNAs from a Caribbean Soft Coral
}

Jose V. Lopez

Nova Southeastern University, <<span class="elink">joslo@nova.edu

Angela Ledger

Florida Atlantic University

Lory Z. Santiago-Vázquez

Florida Atlantic University

Mihai Pop

University of Maryland

Dan D. Sommer

University of Maryland

See next page for additional authors

Find out more information about Nova Southeastern University and the Halmos College of Natural Sciences and Oceanography.

Follow this and additional works at: https://nsuworks.nova.edu/occ_facarticles

Part of the Marine Biology Commons, and the Oceanography and Atmospheric Sciences and Meteorology Commons

\section{Recommended Citation}

Lopez, Jose V., Angela Ledger, Lory Z. Santiago-Vazquez, Mihai Pop, Dan D. Sommer, Llanie K. Ranzer, Robert A. Feldman, and Russell G. Kerr. "Suppression Subtractive Hybridization PCR Isolation of cDNAs from a Caribbean Soft Coral." Electronic Journal of Biotechnology. no. 1 (2011). 10.2225/vol14-issue1-fulltext-3.

This Article is brought to you for free and open access by the Department of Marine and Environmental Sciences at NSUWorks. It has been accepted for inclusion in Marine \& Environmental Sciences Faculty Articles by an authorized administrator of NSUWorks. For more information, please contact nsuworks@nova.edu. 
Authors

Llanie K. Ranzer

Florida Atlantic University

Robert A. Feldman

SymBio Corporation

Russell G. Kerr

Florida Atlantic University 


\title{
Suppression subtractive hybridization PCR isolation of cDNAs from a Caribbean soft coral
}

\author{
Jose V. Lopez ${ }^{1,2,3} \square \cdot$ Angela Ledger ${ }^{2} \cdot$ Lory Z. Santiago-Vázquez ${ }^{3,4} \cdot$ Mihai Pop $^{5} \cdot$ Dan D. Sommer ${ }^{5}$ \\ Llanie K. Ranzer ${ }^{3,6} \cdot$ Robert A. Feldman ${ }^{7} \cdot$ Russell G. Kerr ${ }^{3,8}$ \\ 1 Oceanographic Center, Nova Southeastern University, Dania Beach, FL, USA \\ 2 Florida Atlantic University at Harbor Branch Oceanographic Institution Fort Pierce, FL, USA \\ 3 Department of Chemistry and Biochemistry, Florida Atlantic University, Boca Raton, FL, USA \\ 4 Natural Sciences Division, University of Houston, Clear Lake, Houston, TX, USA \\ 5 Center for Bioinformatics and Computational Biology, University of Maryland, College Park, MD, USA \\ 6 Biotechnology Department, Keiser University, Port St. Lucie, FL, USA \\ 7 SymBio Corporation, Menlo Park, CA, USA \\ 8 Department of Chemistry, University of Prince Edward Island, Charlottetown, PEI, Canada
}

$\triangle$ Corresponding author: joslo@nova.edu

Received March 27, 2010 / Accepted November 16, 2010

Published online: January 15, 2011

C 2011 by Pontificia Universidad Católica de Valparaíso, Chile

\begin{abstract}
Transcriptomic studies of marine organisms are still in their infancy. A partial, subtracted expressed sequence tag (EST) library of the Caribbean octocoral Erythropodium caribaeorum and the sea fan Gorgonia ventalina has been analyzed in order to find novel genes or differences in gene expression related to potential secondary metabolite production or symbioses. This approach entails enrichment for potential non-"housekeeping" genes using the suppression subtractive hybridization (SSH) polymerase chain reaction (PCR) method. More than 500 expressed sequence tags (ESTs) were generated after cloning SSH products, which yielded at least 53 orthologous groups of proteins (COGs) and Pfam clusters, including transcription factors (Drosophila Big Brother), catalases, reverse transcriptases, ferritins and various "hypothetical" protein sequences. A total of 591 EST sequences were deposited into GenBank [dbEST: FL512138 - FL512331, GH611838, and HO061755-HO062154]. The results represent proof of concept for enrichment of unique transcripts over housekeeping genes, such as actin or ribosomal genes, which comprised approximately $17 \%$ of the total dataset. Due to the gene and sequence diversity of some ESTs, such sequences can find utility as molecular markers in current and future studies of this species and other soft coral biogeography, chemical ecology, phylogenetics, and evolution.
\end{abstract}

Keywords: cDNA, Erythropodium caribaeorum, EST, Gorgonia ventalina, gorgonian, sea fan

\section{INTRODUCTION}

Knowing the complete nucleotide genome sequence of any given organism does not guarantee complete elucidation of its molecular biology. For a more accurate profile of ongoing cellular processes, attention must turn to the mRNA transcripts and resulting proteins and enzymes (the phenotype) encoded by the nuclear genome. For this reason, the fields of genomics, transcriptomics, and proteomics all help advance our understanding of basic cellular metabolism (DeLong et al. 2006; Koonin and Wolf, 2006), and this paper focuses on the second tier of mRNA analyses.

Genomics and other "omics" analyses of marine organisms have only recently begun. Many marine invertebrates spark interest for their ecology and residence in unique and threatened habitats (coral reefs), or because they produce bioactive and potentially therapeutic natural products (Newman and Cragg, 2004). For example, the bryozoan Bugula neretina, in conjunction with a microbial endosymbiont, produces the macrocyclic lactone Bryostatin-1, which has been shown to have 
Lopez et al.

immunomodulatory and anti-tumor capabilities through its modulation of protein kinase C activity (Lopanik et al. 2006).

Natural product biosynthesis in scleractinian corals appears relatively less pronounced, perhaps because these organisms already have other protective mechanisms, such as nematocysts, a hard skeleton, and mucus production. However, octocorals (soft corals) can yield a diverse array of terpenoids, such as the anti-inflammatory and analgesic agents, the pseudopterosins, derived from the octocoral Pseudopterogorgia elisabethae (Look et al. 1986). Another octocoral, the common encrusting gorgonian, Erythropodium caribaeorum (EC) fastens to rocky substrate on Floridian and Caribbean coral reefs. This coral is known for the production of eleutherobin, a potent terpenoid chemotherapeutic agent with high activity against breast, renal, and lung cancer, and a mechanism of action similar to Taxol ${ }^{\mathrm{TM}}$. In addition to the anti-cancer activities, diterpene biosynthetic intermediates of EC have been shown to also have antimitotic properties (Britton et al. 2001). The production of these secondary metabolites within the octocoral has indicated defensive properties that deter predation by reef fish (Fenical and Pawlik, 1991). This study stemmed from a primary goal to characterize key biosynthetic enzymes (e.g. diterpene synthases), central to the production of eleutherobin by EC or its symbionts.

The approach to find potential biosynthetic pathway genes related to eleutherobin or other secondary metabolism was based on enrichment. Genomic studies suggest that highly expressed housekeeping or "core" genes probably evolve more slowly, while rare (but active) transcripts exhibit more divergent sequences (Green et al. 1993). This is reasonable, if it is assumed that the cell has to "test" novel sequences before committing a large amount of metabolic energy into its coding and translation of a potentially useless protein (Krylov et al. 2003). Thus, this study aims to bypass most housekeeping transcripts by enriching for novel sequences via the utilization of suppression subtractive hybridization polymerase chain reaction (PCR) (Diatchenko et al. 1999). This method has been previously applied to find symbiosis-specific genes (Rodriguez-Lanetty et al. 2006). Other studies have applied transcriptomic analyses to soft corals, but only the more recent high throughput studies have yielded expressed sequence tags (EST) sequence data (Overbeek et al. 2005; Hoover et al. 2007; Hoover et al. 2008; Schwarz et al. 2008). The present study also represents an exercise to apply mRNA enrichment methods to a non-model marine coral (rather than Montastraea or Acropora). Gorgonia ventalina was used as the suppression subtractive hybridization (SSH) reference strain (driver) since it has different and fewer secondary metabolites than the target Erythropodium caribaeorum. Similar to M. Matz's and other initiatives to allow more open access to DNA sequences (http://www.bio.utexas.edu/research/matz lab/matzlab/Data.html) it is expected that the release of these data can spur further experiments and hypothesis testing in coral species.

\section{MATERIALS AND METHODS}

\section{Sample and RNA extraction}

EC was collected by SCUBA at Dania Beach, Fort Lauderdale, Florida, USA at a depth of $10 \mathrm{~m}$. Gorgonia ventalina (GV) samples were obtained from live cultured specimens at Harbor Branch Oceanographic Institution. All samples were immediately frozen in liquid nitrogen and stored at $-80^{\circ} \mathrm{C}$ or placed in RNALater upon collection and stored at $-20^{\circ} \mathrm{C}$.

Total RNA from EC and from GV was extracted using the RNeasy Plant Mini kit (Qiagen, Valencia, CA, USA) or RNAwiz reagents (Ambion, Austin, TX, USA) according to manufacturers' instructions. Microbial RNA was not separated from eukaryotic mRNA during this process. DNA digestion was performed with Amplification Grade DNAse I (Invitrogen, Carlsbad, CA, USA). RNA quantity was assessed by spectrophotometry (A260/A280), while RNA quality was assessed by gel electrophoresis.

\section{SSH PCR}

cDNA synthesis was performed with approximately $3 \mu \mathrm{g}$ of total RNA. Enrichment via EC vs. GV for suppression subtractive hybridization PCR (EC x GV SSH PCR) to obtain novel non-housekeeping transcripts was accomplished with a combination of SuperSmart PCR cDNA Synthesis (oligo dT primers) and PCR-Select ${ }^{\mathrm{TM}}$ cDNA Subtraction Kits (Clontech, Mountain View, CA, USA). The pCRII 
Topo TA plasmid vector (Invitrogen) was then used to clone enriched cDNAs after their PCR amplification with supplied adapters and primers.

\section{Sequencing}

Sequences were generated by Symbio Corporation (Menlo Park, CA) on ABI 3730xI DNA sequence analyzers. The resulting chromatograms (.scf extension) were base called via Phred (Ewing et al. 1998) which generated quality scores for each nucleotide. Phred quality scores are on a logarithmic scale, with a score of 20 (Q20) indicating a 99\% probability that the base was called correctly.

Table 1. Representative E. caribaeorum EST and unigenes after BLASTX searches.

\begin{tabular}{|c|c|c|c|c|c|}
\hline EC clone & $\begin{array}{l}\text { GenBank Best } \\
\text { Hit (Acc. No.) }\end{array}$ & Top BLASTX Hit Description & $\begin{array}{l}\text { Gen-Bank } \\
\text { No. }\left({ }^{*}\right)\end{array}$ & Score & E Value \\
\hline $353 \mathrm{C}$ & XP_002786203 & $\begin{array}{c}\text { RAS small GTpases } \\
\text { RIC1/ypt1, putative } \\
\text { [Perkinsus marinus ATCC 50983] }\end{array}$ & FL512138 & 168 & $4.00 \mathrm{E}-47$ \\
\hline $353 P$ & XP_002433402 & $\begin{array}{l}\text { UDP-galactose transporter, putative [Ixodes } \\
\text { scapularis] }\end{array}$ & GH611838 & 114 & $1.00 \mathrm{E}-23$ \\
\hline $355 \mathrm{M}$ & ABK29471 & $\begin{array}{c}\text { CHK1 checkpoint-like protein [Helicoverpa } \\
\text { armigera] }\end{array}$ & FL512144 & 88.6 & $2.00 \mathrm{E}-16$ \\
\hline $356 \mathrm{BV}$ & ABA28990 & $\begin{array}{l}\text { DNA J-like protein } 2 \\
\text { [Symbiodinium } \mathrm{sp} . \mathrm{C} 3 \text { ] }\end{array}$ & FL512146 & 125 & $1.00 \mathrm{E}-27$ \\
\hline $356 \mathrm{CP}$ & NP_001174722 & $\begin{array}{c}\text { Os06g0286310 } \\
\text { [Oryza sativa Japonica Group] }\end{array}$ & FL512148 & 91.7 & $3.00 \mathrm{E}-17$ \\
\hline $356 \mathrm{U}$ & XP_002112452 & $\begin{array}{c}\text { Expressed hypothetical protein [Trichoplax } \\
\text { adhaerens] }\end{array}$ & FL512151 & 136 & $9.00 \mathrm{E}-31$ \\
\hline $382 \mathrm{AP}$ & XP_001624566 & $\begin{array}{l}\text { Core-binding factor subunit beta } \\
\text { [Nematostella vectensis] and } \\
\text { Big brother CG7959-PA } \\
\text { [Drosophila melanogaster] }\end{array}$ & FL512174 & 199 & $2 \mathrm{E}-49$ \\
\hline $382 \mathrm{AY}$ & XP_001624566 & $\begin{array}{l}\text { Core-binding factor subunit beta } \\
\text { [Nematostella vectensis] and } \\
\text { Big brother CG7959-PA } \\
\text { [Drosophila melanogaster] }\end{array}$ & FL512176 & 193 & $1.00 \mathrm{E}-47$ \\
\hline $382 \mathrm{DI}$ & XP_002742298 & $\begin{array}{l}\text { PREDICTED: ferritin-like protein-like } \\
\text { [Saccoglossus kowalevskii] }\end{array}$ & FL512182 & 149 & $9.00 \mathrm{E}-37$ \\
\hline $382 \mathrm{DV}$ & XP_002742298 & $\begin{array}{l}\text { PREDICTED: ferritin-like protein-like } \\
\text { [Saccoglossus kowalevskin] }\end{array}$ & FL512192 & 172 & $5.00 \mathrm{E}-42$ \\
\hline $382 \mathrm{FD}$ & ZP_06579711 & $\begin{array}{c}\text { Putative reverse transcriptase [Zingiber } \\
\text { officinale] }\end{array}$ & FL512203 & 94.7 & $2.00 \mathrm{E}-17$ \\
\hline $386 \mathrm{C}$ & $\begin{array}{c}\text { AAF91388 } \\
\text { XP_001676261 }\end{array}$ & $\begin{array}{c}\text { SocE } \\
\text { [Myxococcus xanthus] }\end{array}$ & FL512217 & 99.4 & $2.00 \mathrm{E}-19$ \\
\hline $418 \mathrm{BB}$ & XP_002644180 & $\begin{array}{l}\text { Hypothetical protein CBG17156 } \\
\text { [Caenorhabditis briggsae] }\end{array}$ & FL512261 & 51.6 & $1.00 \mathrm{E}-04$ \\
\hline $418 \mathrm{BC}$ & ZP_03289628 & $\begin{array}{l}\text { Hypothetical protein CLONEX_01831 } \\
\text { [Clostridium nexile DSM 1787] }\end{array}$ & FL512262 & 142 & $1.00 \mathrm{E}-31$ \\
\hline $386 \mathrm{~B}$ & ZP_03104354 & SocE [Bacillus cereus $W$ ] & FL512216 & 80.9 & $5.00 \mathrm{E}-14$ \\
\hline $386 \mathrm{AB}$ & NP_608540 & $\begin{array}{l}\text { CG2839 CG2839-PA } \\
\text { [Drosophila melanogaster] }\end{array}$ & FL512212 & 37.4 & $1.00 \mathrm{E}-04$ \\
\hline $386 \mathrm{~K}$ & XP_001633321 & $\begin{array}{c}\text { Predicted protein } \\
\text { [Nematostella vectensis] }\end{array}$ & FL512221 & 71.2 & $4.00 \mathrm{E}-11$ \\
\hline $422 \mathrm{E}-1$ & XP_001633321 & $\begin{array}{l}\text { Predicted protein } \\
\text { [Nematostella vectensis] }\end{array}$ & FL512303 & 68.2 & 2.00E-09 \\
\hline $419 \mathrm{CJ}$ & XP_002165056 & $\begin{array}{c}\text { PREDICTED: similar to acidic ribosomal } \\
\text { protein A1 } \\
\text { [Hydra magnipapillata }]\end{array}$ & FL512277 & 101 & 7.00E-20 \\
\hline $381 \mathrm{AY}$ & XP_002128607 & $\begin{array}{l}\text { PREDICTED: similar to actin } \\
\text { [Ciona intestinalis] }\end{array}$ & FL512160 & 182 & $1.00 \mathrm{E}-44$ \\
\hline
\end{tabular}

(*) Newly assigned GenBank EST Accession \# for the corresponding EC clone shown in first column. 


\section{Bioinformatics data analyses}

The sequences were mapped, 6-frame translated, to the NR protein database, using the BLASTX option in NCBI BLAST (http://blast.ncbi.nlm.nih.gov/). Matches with E-value $<10^{-2}$ were further analyzed using in-house scripts that select the most specific gene annotations from among all the highquality alignments to proteins in the database. This procedure is necessary in order to avoid a common annotation error caused by situations where the top BLAST hit has a non-specific label (e.g. hypothetical protein) yet other high-quality matches exist that have been assigned a specific functional label.

Putative housekeeping genes were identified through keyword searches using a manually curated list of keywords associated with highly expressed microbial (Karlin and Mrazek, 2000) and eukaryotic genes (Eisenberg and Levanon, 2003). Furthermore, each gene was assigned to one of the three groups (Eukaryotes, Prokaryotes or Viruses) based on the taxonomic assignment of the nearest BLAST hit when such an assignment was available in the database.

Sequence Submission. Novel ECEST sequences were deposited into GenBank (dbEST: FL512138FL512331, GH611838, and HO061755-HO062154).

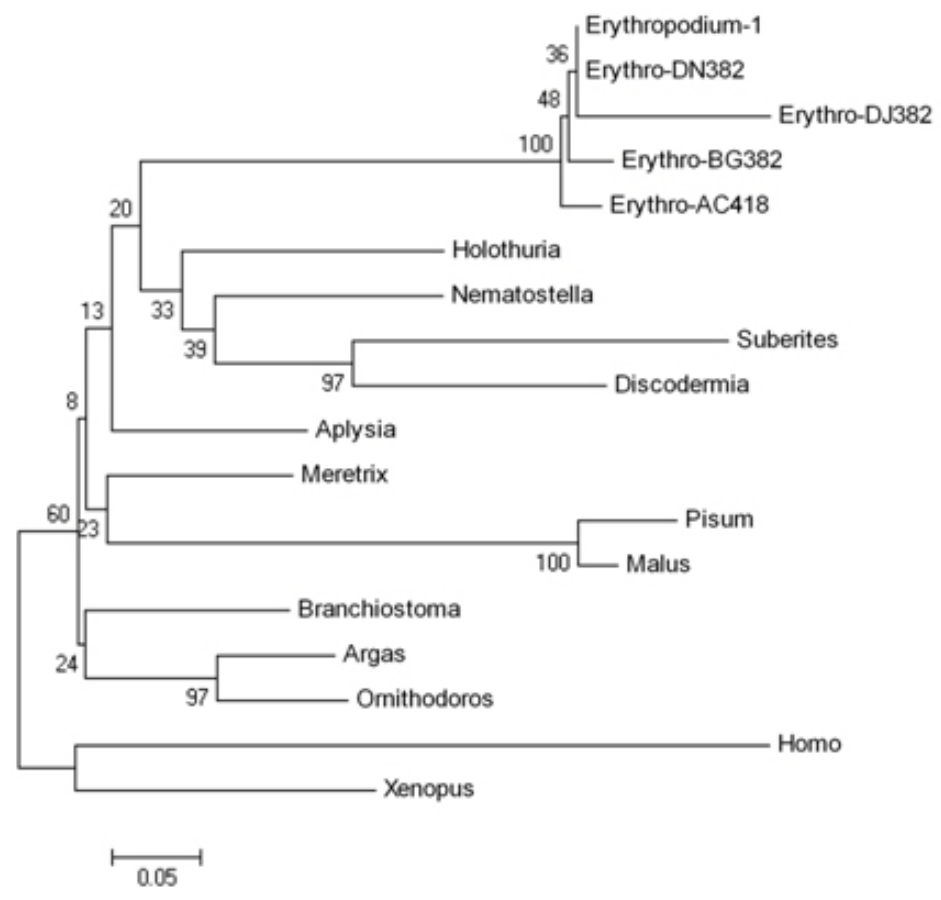

Fig. 1. Evolutionary relationships of ferritin of $\mathbf{1 8}$ taxa inferred from amino acid sequences using the Minimum Evolution (ME) method (Rzhetsky and Nei, 1992). The bootstrap consensus tree inferred from 100 replicates is taken to represent the evolutionary history of the taxa analyzed. The percentage of replicate trees in which the associated taxa clustered together in the bootstrap test (100 replicates) is shown next to the branches (Felsenstein, 1985). The tree is drawn to scale, with branch lengths equal to the evolutionary distances used to infer the phylogenetic tree. The evolutionary distances were computed using the Poisson correction method (Zuckerkandl and Pauling, 1965) and are in the units of the number of amino acid substitutions per site. The ME tree was searched using the Close-Neighbor-Interchange (CNI) algorithm (Nei and Kumar, 2000) at a search level of 3. All positions containing gaps and missing data were eliminated from the dataset (complete deletion option). There were a total of 107 positions in the final dataset. Phylogenetic analyses were conducted with MEGA4 (Tamura et al. 2007). Erythropodium accession numbers are listed in the text, while accession numbers for reference sequences are as follows: Nematostella vectensis - XP_001632011; Aplysia californica ABF21074.1; Suberites ficusgi - CAG25529.1; Dermatophagoides pteronyssinus AAG02250; Argas monolakensis - ABI52633; Holothuria glaberrima - ABS29643; Ornithodoros parkeri - ABR23389; Meretrix meretrix - CAB72315; Dermacentor andersoni - AAG02250.1; Pisum sativum - CAA51786.1; Xenopus laevis AAB20316.1; Branchiostomagi belcheri - AAQ21039.1; Malus xiaojinensis - AAK83702.1|AF315505_1; Homo sapiens - CCDS33070.1. 


\section{RESULTS AND DISCUSSION}

More than 591 EST sequences were generated in this study, with 238 ESTs [dbEST: FL512138 FL512331, GH611838, and HO061755-HO062154] having significant matches against proteins in the NR database. Table 1 shows a sample representation of the top sequence identities obtained after BLASTX searches, showing relatively high hit scores and significant $E$ values. As expected, a considerable fraction of EST hits (37 sequences) showed similarities to the sequenced anthozoan Nematostella vectensis genome (Sullivan et al. 2006). A large fraction of these sequences (25) had matches to unknown $N$. vectensis proteins (e.g. 358A, $382 \mathrm{EL}$ ) while the others matched a predicted core-binding factor (e.g. 382AF, 382AP).

Among potential primary (core) metabolic genes, only 15 actin sequences were identified in this limited dataset with identity matches to diverse taxa. Only one ribosomal related sequence was identified. Comprehensive profiles of different gene categories are shown in Table 2.

The majority of the sequences found (73.1\%) appear to be of eukaryotic origin. This result was expected due to the use of oligo dT primers during first strand cDNA synthesis that typically tend to minimize the presence of prokaryotic and bacterial sequences, although the presence of these is still expected. Also, the EC dataset showed a high proportion of hypothetical sequences, consistent with similar analyses of larger EST datasets derived from 454 sequencing (Meyer et al. 2009). At least 60 "unknown" or "hypothetical" sequence designations comprised a large proportion of database matches in this dataset (19\% of the eukaryotic and $46 \%$ of prokaryotic sequences, respectively), while several other gene categories also appeared in relatively high proportions, such as 22 total ferritin sequences (9.3\%), 16 Myxococcus and Bacillus SocE proteins (6.7\%), and 7plant reversetranscriptase sequences $(2.9 \%)$.

Specific EC cDNAs, such as several transcription factors (with lower scoring thresholds), similar to those previously characterized in cnidarians (Seipel et al. 2004) also appear to have been detected. Within this category, ten clones such as 382AF and 382AP matched to a predicted core-binding factor in Nematostella vectensis, and a protein homologous to the Drosophila protein Big Brother, which has transcriptional regulatory functions (Kaminker et al. 2001). Another clone (386 R) showed similarity to a galaxin protein found in coral exoskeletons and used in coral systematics (Wirshing and Baker, 2008).

A small portion (12\% or 22 sequences) of the 172 of the eukaryotic ESTs also grouped into iron-sulfur assemblages that included ferritin-like proteins. As stated above, ferritin represents a ubiquitous iron storage protein (found in animals, plants, bacteria, and archaea) with key functions of iron detoxification and sequestration (Harrison and Arosio, 1996). Ferritin has also been implicated in redox stress responses (Rocha and Smith, 2004; Theil, 2007).

Table 2. Erythropodium caribaeorum ESTs.

\begin{tabular}{|ccc|}
\hline Category & ESTs Number & \% of Total \\
\hline Total & 591 & 100 \\
\hline Eukaryotes & 174 & 29.44 \\
\hline Prokaryotes & 62 & 10.49 \\
\hline Viruses & 1 & 0.17 \\
\hline Unknown & 1 & 0.17 \\
\hline No hit & 353 & 59.73 \\
\hline Euk hypothetical & 32 & 18.39 \\
\hline Euk housekeeping & 30 & 17.24 \\
\hline Euk other & 112 & 64.37 \\
\hline Prok hypothetical & 28 & 45.16 \\
\hline Prok housekeeping & 0 & 0.00 \\
\hline Prok other & 34 & 54.84 \\
\hline
\end{tabular}


Lopez et al.

Alignments and cursory phylogenetic analysis of diverse ferritin amino acid sequences were performed to place the present EC ferritin sequences within a taxonomic framework (Figure 1). The alignment revealed the presence of conserved tyrosine sequences and extends the finding of Schwarz et al. (2008) that indicated several conserved motifs, likely relevant to ferritin function, which could be used for future primer or probe design. The minimum evolution trees showed that EC sequences allied with each other formed a weak clade with other marine invertebrates, but not close with the cnidarian Nematostella. The ambiguity of positioning may be due to homoplasious residues in ferritin sequences, suggesting potential drawbacks as a deep phylogenetic marker despite the protein's likely ancient origin. Although paralogous EC ferritin sequences are possible, the number of potential coral-derived ferritins derived from this subtraction may highlight the importance of this protein for the coral or its microbial community.

As expected, bacterial and protozoan sequences were also detected in the library, albeit in fewer numbers (62 sequences - $26 \%$ ), and could be associated with either transient or resident symbionts associated with the corals (Lopez et al. 2010). For example, sequences included a SocE gene, involved in protein degradation and amino acid scavenging in Myxococcus, a Streptomyces twocomponent system sensor kinase, and diverse Clostridium, Arthrobacter sp. and Plasmodium chabaudi hypothetical sequences.

Although the inclusion of specific metabolic genes or organismal source of these products has not yet been validated by quantitative PCR (qPCR), the current expression SSH analyses places the ECderived sequences in an interesting context. For example, these genes may be active in distantly related species, or may represent expression of rare genes. It would also be interesting to test for the expression of novel transcription factor sequences, which may be correlated with secondary metabolite biosyntheses.

It was unfortunate that the originally targeted eleutherobin or related diterpene synthase genes were undetected in this study. However to date, relatively few diterpene genes have been characterized or isolated, with none from marine organisms. Moreover, very few biosynthetic pathway genes appeared to be detected with the exception of a putative RTX toxin (ZP_01442131). Nonetheless, this does not preclude the possibility that biosynthetic gene sequences occur among the 353 EC EST sequences that show no hits with current databases. For example, proteins similar to those in the moenomycinproducer Streptomyces ghanaensis genome appear to be present in the Erythropodium dataset.

One could also begin to monitor gene expression variation across different coral taxa that would help characterize an unknown sequence's importance and function. For example EC can reside in much different reef substrates than $\mathrm{GV}$ and thus may produce more bioactive natural products as a consequence. Other explanations for a particular cDNA profile may stem from the presence of specific microbial associates or environmental cues. Overall, this study shows the utility and benefits of enriching and subtracting cDNAs to remove abundant core genes, identify novel genes, metabolic pathways, or variation in gene expression related to particular ecologies (Matus et al. 2008). The 591 soft coral ESTs (with 353 without hits) newly isolated for this study represent a valuable library since the majority of the published genetic sequence data belongs to hard corals but not much work has been devoted to soft corals.

\section{ACKNOWLEDGMENTS}

The authors would like to thank the anonymous reviewer for their valuable comments and insights that helped to greatly improve this manuscript.

Financial support: The authors gratefully acknowledge financial support from Florida Sea Grant College (R/LRMB-23 to JVL and R/LR-MB-14 to RK). This material is also based upon worked supported by the National Science Foundation under a grant awarded to L.Z. Santiago-Vázquez (awards \#0310283 and 0514500). MP and DDS were supported in part the NIH grant R01-HG-0004885 to MP. 


\section{REFERENCES}

BRITTON, R.; ROBERGE, M.; BERISCH, H. and ANDERSEN, R.J. (2001). Antimitotic diterpenoids from Erythropodium caribaeorum: Isolation artifacts and putative biosynthetic intermediates. Tetrahedron Letters, vol. 42, no. 16, p. 2953-2956. [CrossRef]

DELONG, E.F.; PRESTON, C.M.; MINCER, T.; RICH, V.; HALLAM, S.J.; FRIGAARD, N.U.; MARTINEZ, A.; SULLIVAN, M.B.; EDWARDS, R.R.; RODRIGUEZ BRITO, B.; CHISHOLM, S.W. and KARL, D.M. (2006). Community genomics among stratified microbial assemblages in the ocean's interior. Science, vol. 311, no. 5760, p. 496-503. [CrossRef]

DIATCHENKO, L.; LUKYANOV, S.; LAU, Y.F.C. and SIEBERT, P.D. (1999). Suppression subtractive hybridization: A versatile method for identifying differentially expressed genes. Methods in Enzymology, vol. 303, p. 349380. [CrossRef]

EISENBERG, E. and LEVANON, E.Y. (2003). Human housekeeping genes are compact. Trends in Genetics, vol. 19, no. 7, p. 362-365. [CrossRef]

EWING, B.; HILLIER, L.; WENDL, M. and GREEN, P. (1998). Base-calling of automated sequencer traces using Phred. I: Accuracy assessment.Genome Research, vol. 8, no. 3, p. 175-185.

FELSENSTEIN, J. (1985). Confidence limits on phylogenies: An approach using the bootstrap. Evolution, vol. 39, no. 4 p. 783-791.

FENICAL, W. and PAWLIK, J.R. (1991). Defensive properties of secondary metabolites from the Caribbean gorgonian coral Erythropodium caribaeorum. Marine Ecology Progress Series, vol. 75, p. 1-8. [CrossRef]

GREEN, P.; LIPMAN, D.; HILLIER, L.; WATERSTON, R.; STATES, D. and CLAVERIE, J.M. (1993). Ancient conserved regions in new gene sequences and the protein databases. Science, vol. 259, no. 5102, p. 17111716. [CrossRef]

HARRISON, P.M. and AROSIO, P. (1996). The ferritins: Molecular properties, iron storage function and cellular regulation. Biochimica et Biophysica Acta (BBA) - Bioenergetics, vol. 1275, no. 1-2, p. 161-203. [CrossRef]

HOOVER, C.A.; SLATTERY, M. and MARSH, A.G. (2007). Profiling transcriptome complexity and secondary metabolite synthesis in a benthic soft coral, Sinularia polydactyla. Marine Biotechnology,vol. 9, no. 2, p. 166178. [CrossRef]

HOOVER, C.A.; SLATTERY, M.; TARGETT, N.M. and MARSH, A.G. (2008). Transcriptome and metabolite responses to predation in a South Padic soft coral. Biological Bulletin, vol. 214, no. 3, p. 319-328.

KAMINKER, J.S.; SINGH, R.; LEBESTKY, T.; YAN, H. and BANERJEE, U. (2001). Redundant function of runt domain binding partners, Big brother and Brother, during Drosophila development. Development, vol. 128, no. 14 , p. $2639-2648$.

KARLIN, S. and MRÁZEK, J. (2000). Predicted highly expressed genes of diverse prokaryotic genomes. The Journal of Bacteriology, vol. 182, no. 18, p. 5238-5250. [CrossRef]

KOONIN, E.V. and WOLF, Y.I. (2006). Evolutionary systems biology: links between gene evolution and function. Current Opinion in Biotechnology, vol. 17, no. 5, p. 481-487. [CrossRef]

KRYLOV, D.M.; WOLF, Y.I.; ROGOZIN, I.B. and KOONIN, E.V. (2003). Gene loss, protein sequence divergence, gene dispensability, expression level, and interactivity are correlated in eukaryoticevolution. Genome Research, vol. 13, no. 10, p. 2229-2235. [CrossRef]

LOOK, S.A.; FENICAL, W.; JACOBS, R.S. and CLARDY, J. (1986). The pseudopterosins: anti-inflammatory and analgesic natural products from the sea whip Pseudopterogorgia elisabethae. Proceedings of the National Academy of Sciences of the Unites States of America, vol. 83, no. 17, p. 6238-6240. [CrossRef]

LOPANIK, N.B.; TARGETT, N.M. and LINDQUIST, N. (2006). Isolation of two polyketide synthase gene fragments from the uncultured microbial symbiont of the marine bryozoan Bugula neritina. Applied and Environmental Microbiology, vol. 72, no. 12, p. 7941-7944. [CrossRef]

LOPEZ, J.V.; RANZER, L.K.; LEDGER, A.; SCHOCH, B., DUCKWORTH, A.; MCCARTHY, P.J. and KERR, R.G. (2010). Comparison of bacterial diversity within the coral reef sponge, Axinella corrugata, the encrusting coral Erythropodium caribaeorum. In: Proceedings of the International Coral Reef Symposium, (11 ${ }^{\text {th }}$, July 7-11, 2008, Ft. Lauderdale, Florida, USA). Mini-Symposium 26: Biodiversity and Diversification of Reef Organism. p. 1355-1359.

MATUS, D.Q.; MAGIE, C.R.; PANG, K.; MARTINDALE, M.Q. and THOMSEN, G.H. (2008). The Hedgehog gene family of the cnidarian, Nematostella vectensis, and implications for understanding metazoan Hedgehog pathway evolution. Developmental Biology, vol. 313, no. 2, p. 501-518. [CrossRef]

MEYER, E.; AGLYAMOVA, G.V.; WANG, S.; BUCHANAN-CARTER, J.; ABREGO, D.; COLBOURNE, J.K.; WILLIS, B.L. and MATZ, M.V. (2009). Sequencing and de novo analysis of a coral larval transcriptome using 454 GSFIx. BMC Genomics, vol. 10, no. 219. [CrossRef]

NEI, M. and KUMAR, S. (2000). Molecular evolution and phylogenetics. New York, Oxford Uiversity Press. 3336 p. ISBN 0-19-513585-7.

NEWMAN, D.J. and CRAGG, G.M. (2004). Marine natural products and related compounds in clinical and advanced preclinical trials. Journal of Natural Products, vol. 67, no. 8, p. 1216-1238. [CrossRef]

OVERBEEK, R.; BEGLEY, T.; BUTLER, R.M.; CHOUDHURI, J.V.; CHUANG, H.Y.; COHOON, M.; DE CRÉCYLAGARD, V.; DIAZ, N.; DISZ, T.; EDWARDS, R.; FONSTEIN, M.; FRANK, E.D.; GERDES, S.; GLASS, E.M.; GOESMANN, A.; HANSON, A.; IWATA-REUYL, D.; JENSEN, R.; JAMSHIDI, N.; KRAUSE, L.; KUBAL, M.; LARSEN, N.; LINKE, B.; MCHARDY, A.C; MEYER, F.; NEUWEGER, H.; OLSEN, G.; OLSON, R.; OSTERMAN, A.; PORTNOY, V.; PUSCH, G.D.; RODIONOV, D.A.; RÜCKERT, C.; STEINER, J.; STEVENS, R.; THIELE, I.; VASSIEVA, O.; YE, Y.; ZAGNITKO, O. and VONSTEIN, V. (2005).The subsystems approach to genome annotation and its use in the project to annotate 1000 genomes. Nucleic Acid Research, vol. 33, no. 17, p. 5691-5702. [CrossRef] 
ROCHA, E.R. and SMITH, C.J. (2004). Transcriptional regulation of the Bacteroides fragilis ferritin gene (ftnA) by redox stress. Microbiology, vol. 150, no. 7, p. 2125-2134. [CrossRef]

RODRIGUEZ-LANETTY, M.; PHILLIPS, W.S. and WEIS, V.M. (2006). Transcriptome analysis of a cnidarian dinoflagellate mutualism reveals complex modulation of host gene expression. BMC Genomics, vol. 7, no. 23. [CrossRef]

RZHETSKY, A. and NEI, M. (1992). A simple method for estimating and testing minimum-evolution trees. Molecular Biology and Evolution, vol. 9, no. 5. p. 945-967.

SCHWARZ, J.A.; BROKSTEIN, P.B.; VOOLSTRA, C.; TERRY, A.Y.; MILLER, D.J.; SZMANT, A.M.; COFFROTH, M.A.; MEDINA, M. (2008). Coral life history and symbiosis: Functional genomic resources for two reef building Caribbean corals, Acropora palmata and Montastraea faveolata.BMC Genomics,vol. 9, no. 97. [CrossRef]

SEIPEL, K.; YANZE, N.; MÜLLER, P.; STREITWOLF, R. and SCHMID, V. (2004). Basic leucine zipper transcription factors C/EBP and MafL in the hydrozoan jellyfish Podocoryne carnea. Developmental Dynamics, vol. 230, no. 3, p. 392-402. [CrossRef]

SULLIVAN, J.C.; RYAN, J.F.; WATSON, J.A.; WEBB, J.; MULLIKIN, J.C.; ROKHSAR,D. and FINNERTY, J.R. (2006). StellaBase: The Nematostella vectensis Genomics Database. Nucleic Acids Research, vol. 34 (Suppl.), no. 1, p. D495-D499. [CrossRef]

TAMURA, K.; DUDLEY, J.; NEI, M. and KUMAR, S. (2007). MEGA4: Molecular Evolutionary Genetic Analysis (MEGA) software version 4.0. Molecular Biology and Evolution, vol. 24, no. 8, p. 1596-1599. [CrossRef]

THEIL, E.C. (2007). Coordinating responses to iron and oxygen stress with DNA and mRNA promoters: The ferritin story. Biometals, vol. 20, no. 3-4, p. 513-521. [CrossRef]

WIRSHING, H.H. and BAKER, A.C. (2008). Coral systematics inferred from the gene galaxin: Exploring phylogenetic relationships using a putative determinant of skeletal morphology. Proceedings of the 11th International Coral Reef Symposium, Ft. Lauderdale, Florida, 7-11 July 2008. Session number 26. p. 14011405.

ZUCKERKANDL, E. and PAULING, L. (1965). Part III. Evolutionary divergence and convergence in proteins. In: BRYSON, V. and VOGEL, H.J. eds. Evolving Genes and Proteins. New York, Academic Press. p. 97-166.

\section{How to cite this article:}

LOPEZ, J.V.; LEDGER, A.; SANTIAGO-VÁZQUEZ, L.Z.; POP, M.; SOMMER, D.D.; RANZER, L.K.; FELDMAN, R.A. and KERR, R.G. (2011). Suppression subtractive hybridization PCR isolation of cDNAs from a Caribbean soft coral. Electronic Journal of Biotechnology, vol. 13, no. 5. http://dx.doi.org/10.2225/vol14-issue1$\underline{\text { fulltext-3 }}$ 